\title{
$\mathrm{X}$ 線カントレコーダによるスラッグおよび \\ セメントの定量分析
}

築山宏 ${ }^{* *}$ 若 林 忠 男**

(昭和 37 年 3 月 22 日受理)

\section{X-ray Spectrochemical Analysis of Slags and Cements by X-ray Quantorecorder}

\author{
Hiroshi TSUKIYAMA and Tadao WAKABAYASHI
}

(Shimadzu Seisakusho Ltd., Kyoto)

$\mathrm{X}$-ray spectrochemical analysis is successfully applied to determine TFe, $\mathrm{MnO}, \mathrm{CaO}, \mathrm{P}_{2} \mathrm{O}_{5}, \mathrm{SiO}_{2}$, $\mathrm{Al}_{2} \mathrm{O}_{3}$ in slags and cement by the use of $\mathrm{X}$-ray quantorecorder which can analyze simultaneously up to twelve elements that compose the samples in one to five minutes.

Each of the samples is briquetted in Al-ring of $27 \mathrm{~mm}$ dia. by a press at $10,000 \mathrm{~kg}$ to avoid errors caused by ununiformity of packing.

The errors of analysis found from working curves are comparable to theoretical errors calculated from reproducibility. This gives the possibility of applying the above method to rapid analysis of quality control in iron or steel and cement industries.

1. 緒言

䖝光X線分析法による定量分析法はX線分析装置の改 良にともない急激に進歩し, 実用の段階に入つて来た が，分析をさらに迅速化させることに対してはあまり考 慮が払われなふつた。

著者らは分析の迅速化についても改良安加え, 1959年 に注同時に最高 6 元素が $1 \sim 5$ 分で分析できるX線カン トレコーダを完成したが，今回さらに改良を加え，同時 に最高 12 元素まで分析できるようにし，乙かも走査式 ゴニオメータを加えることにより定性分析も行なえるよ うにした。

本報告では上記装置を使用し，とくに分析困難と思劣 れる鉄鋼スラッグ，セメント等について分析を試みた。

鉄鋼スラッグ，セメント等についてはすでに多くの報 告1)2(3)4) があるが，本報告では特に分析の迅速性を考慮 して測定時間に制限を加え，実際得られた分析精度と10

* 昭和 36 年秋, 日本分光学会, 日本分析化学会にて一 部を発表

** 島津製作所 (京都市中京区西の京桑原町18)
回の繰り返し測定の再現性より期待される理論的精度と の比較検討を行なつた。

\section{2. 実 験 装 置}

\section{1 構 造}

装置は最高 12 元素が同時に分析できるマルチチヤン ネル方式のものであり，Fig. 1 に示されるようにX線発 生・分光部, $\mathrm{X}$ 線計数部・記録部および電源スタビライ ザの 4 部分より構成されている.

分光部の構造活 Fig. 2 に示されているが，試料は下 部より白色 $\mathrm{X}$ 線の照射をうけ, 試料より生じた 2 次螢光

1) 内川・猪股：分析化学， 10, 598 (1961).

2) 内川・猪股：分析化学， 10, 875 (1961).

3) George Andermann, J.L. Johnes and E. Davison: "Advances in X-ray Analysis", Volume 2, p. 215 (1958). (Plenum Press, Inc., New York).

4) George Andermann, J.W. Kemp and M.F. Hasler: Report of International Colloquium on Spectroscopy (June 1961). 
X線法，离らかしめ分析刘象元素に応じて最適の位置に 設定された备スペクトロメータで分光される．この場 合, 太ペタトロタータは分析元素数に志じて最高 12 個

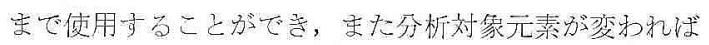

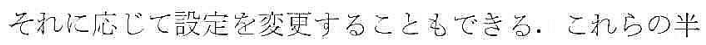
固定武スペクトロメータ灶定量分析のために用いられる

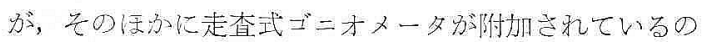
で，定性分析のほか，定量分析に先立古，分析刘象元素 へ粉よ゙す他の介在元素の影響やバックグラウンドの状 態も知ることぶできる。ことに本郝告で取り报つた鉄銅 スラッダなど特に重元装の高次線が軽元标の1次線学妨

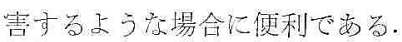

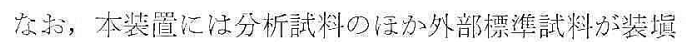
されて和り，モニターとして便用される。忠た，X線通

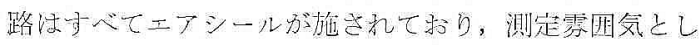

て空気のほか $\mathrm{H}_{2}$, He などの軽がス学琵ぶことができ b.

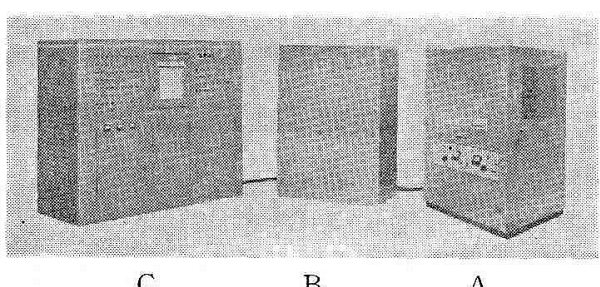

B

A

Fig. 1. Multichannel Type Automatic X-ray Quantorecorder.

(A) X-ray generator and spectrometer unit

(B) Pulse height analyzer and scale down unit

(C) Recorder unit

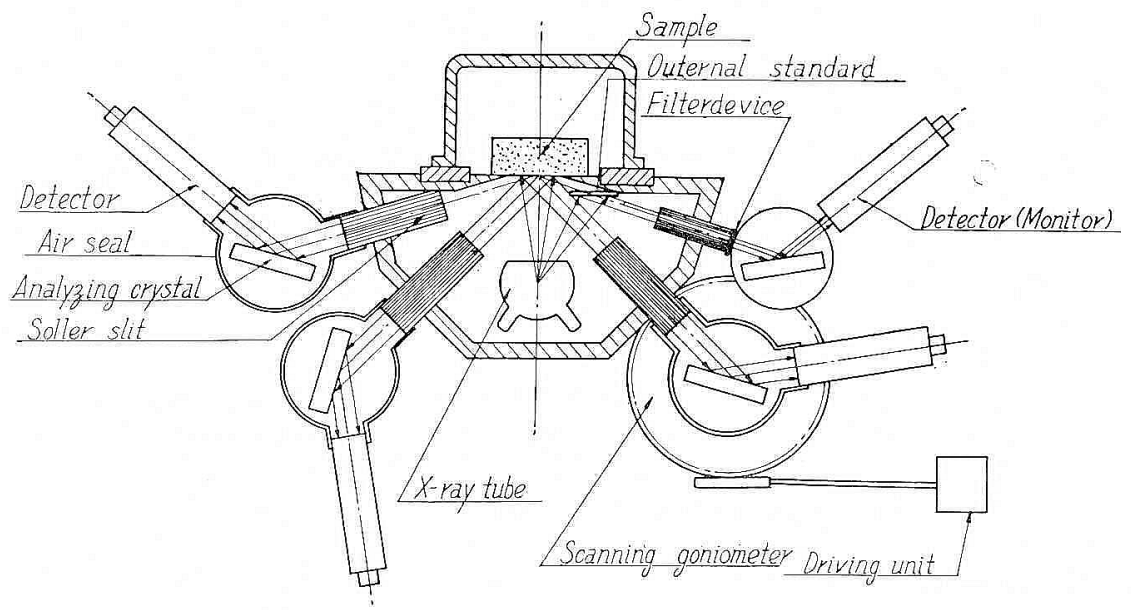

Fig. 2. Schematic diagram of X-ray Quantorecorder optics.

\section{2 測定 原理}

Fig. 3 に本装置のブロッタダイヤグラム然示したが,

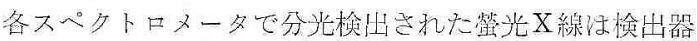
によつてペルスに交換され，計数部へ送られる。

計数部には分析元䕀に応じて增幅，波高巽别あるいは 波高蚠析，スタールダゥン持よでンルス波形整形回路な

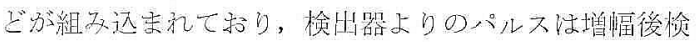
出器の種類によりそ玌ぞれ波高選剔客たは波高分析さ

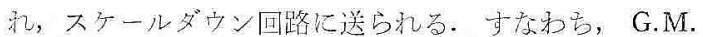

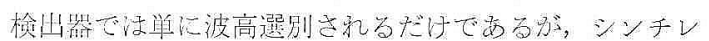
ーション検出器, プロポーショナル榆出器, ガスフロー プロポーショナル検出器などに皮いては，比例増幅㣪波

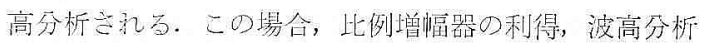

器のベース電压，チャンネルウイソドウ愊などは雒测定

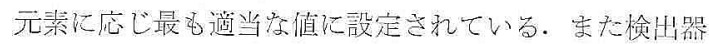
電死も G.M. 检出器の場合はいずれも $1500 \mathrm{~V}$ で使用さ れてい名が、シンチレーショソ，プロポーショナル，ガ スフトープロポーショナル検㟇器の場合は, 測定元敃に 忍じをれでれ最適の電在が巽将れている。

スタールダウンの值は $1 / 2 \sim 1 / 128$ まで 7 四階が設定 さ扎て就り，各元菒のX線強度に応し適当なスタールダ

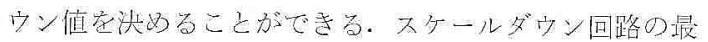

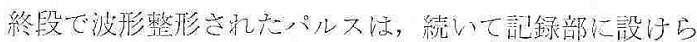
れている積分コンデソサに畒電される。

一方モニターにはプロポーショナル检出器またはシン チレーション检出器などのよらな分船能のすくれれ検出 
器が使用され, X線を単色化のた後検出し, その信号は 比例増幅, 波高分析, 大ケールダウン回路を経て記録部 に設けられている E1T スケーラで計数される.

積分コンデンサへの蓄電は上記スケーラがモニターよ りの信号を計数する間続けられるが，スケーラの計数值 があらかじめ定められている或る計数值に達すると信号 が発せられ積分コンデンサへの蓄電が停止する。

今, 波形整形された出力パルスの振幅を $e$ と, モ二 ターが所定の計数を終えた時分析元素に対応卞る検出器 が $n$ 個のパル大を計数するとすれば，積分コンデンサ の蓄電圧 $E$ 注次式で表わされる。すなわち,

$$
E=C_{c} \cdot e \cdot n /\left(C_{c}+C\right)
$$

ここで $C_{c}$ は大ケールダウン回路と積分コンデンサとの 結合コンデンサの容量, C性積分ニンデンサの容量であ

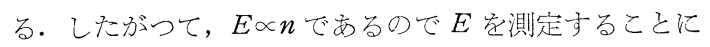
より，モニターの受けるX線量に対する分析元素の強度 比が測定できる. 実際E はリレー機構と振動容量電位計 により次々とレコーダの読多として表わされる．実際の 測定に当つて法, あらかじめ成分溇度既知の標準試料を 用いて検量線叴作成し未知試料の定量走行なう。

なお積分時間は，モニターの受けるX線強度なたはモ ニターに詨応するスケールダウン回路のスケールダウン

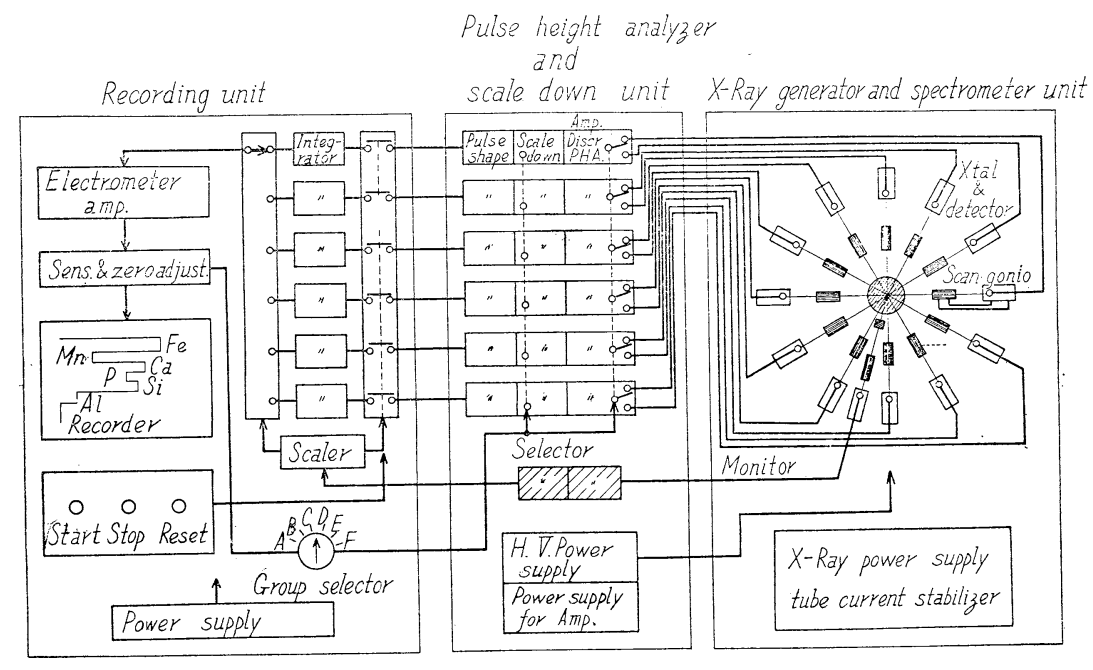

Fig. 3. Block diagram for X-ray Quantorecorder.

值を変えることにより，適宣定めることができる．

\section{3. 実験条件および方法}

\section{1 試料}

分析対象試料法鉄鋼スラッグ A, B 2 禈類およびセメ ントであるが，それらの化学分析值は Table 1 に示さ れている.

試料はスラッグ，セメントともいずれも200〜250メ ッシュ程度の粉体であるが, 試料作成による誤差をなる ベく少なくするためいずれも $2.5 \mathrm{~g}$ を科量し, 内径約 $27 \mathrm{~mm}$ の Al-ring につめ 10 ton の圧力で加圧成型し 実験に供した。試料はバインダを用いる必要もなく約 4 ton の压力でも成型することができたが，10 ton 前後の 圧力が一番良好のようであつた。

\section{2 実験条件}

実験条件は Table 2 に示されているが，この場合全
元素の同時測定であるので, X 線源の強度および積分時 間 (測定時間) の選定は $\mathrm{Al}, \mathrm{Si}, \mathrm{P}$ などのもつとも分析 困難と思われる元素学対象に行つた. したがつて， Fe， $\mathrm{Mn}, \mathrm{Ca}$ などのいわゆる重元素に対してはそれぞれの 検出器の悹にフイルタをとりつけ, 適当な $\mathrm{X}$ 線強度が得 られるようにした。なた, 積分時間は一般に統計変動誤差 と関係があり，長くとればそれだけ統計变動誤差も減少 乙分析精度は向上するが，迅速分析の意義孞失われるの でこの場合 133 秒とし，検量線の作成にはそれぞれ 2 回 の測定を行ないその平均值を採用した.

なお Table 2 の実験条件において Si， Al などの軽 元素を分析する場合, 同一元素であるにかかわらず試料 の種類により波高分析の条件が異なつているのは, 共存 する元素の種類および量が異なつているためである.

すなわち，一般に同一試料中に重元素および軽元素が 存在する場合, 重元素は軽元素に対し種々の影響を与え 
Table 1. Composition of analyzed samples.

\begin{tabular}{|c|c|c|c|c|c|c|c|c|}
\hline \multicolumn{2}{|c|}{ Sample } & \multirow{2}{*}{$\begin{array}{c}\text { T. } \mathrm{Fe} \\
29.5\end{array}$} & \multirow{2}{*}{$\frac{\mathrm{MnO}}{4.96}$} & \multirow{2}{*}{$\frac{\mathrm{CaO}}{27.9}$} & \multirow{2}{*}{$\frac{\mathrm{P}_{2} \mathrm{O}_{5}}{3.80}$} & \multirow{2}{*}{$\frac{\mathrm{SiO}_{2}}{9.76}$} & \multirow{2}{*}{$\frac{\mathrm{Al}_{2} \mathrm{O}_{3}}{2.06}$} & \multirow{2}{*}{$\begin{array}{c}\text { Remarks } \\
\mathrm{S}<0.3\end{array}$} \\
\hline \multirow{7}{*}{ Slag A } & 1 & & & & & & & \\
\hline & 2 & 32.1 & 2.83 & 30.7 & 1.51 & 5.00 & 2.06 & $\mathrm{MgO}<15$ \\
\hline & 3 & 33.1 & 2.05 & 31.7 & 1.06 & 4.50 & 2.06 & \\
\hline & 4 & 43.9 & 1.55 & 26.6 & 0.88 & 3. 40 & 1.54 & \\
\hline & 5 & 41.6 & 1.55 & 25.9 & 0.89 & 3.56 & 1.54 & \\
\hline & 6 & 0.5 & 0.11 & 57.2 & 0.08 & 24.76 & 3.89 & \\
\hline & 7 & 0.6 & 0.14 & 58.8 & 0.11 & 23.80 & 4.96 & \\
\hline \multirow{6}{*}{ Slag B } & 1 & - & 11.18 & 29.13 & - & 42.82 & 7.79 & $\mathrm{~S}<4.0$ \\
\hline & 2 & - & 10.12 & 31.92 & - & 40.16 & 9.86 & \\
\hline & 3 & - & 19.38 & 36.98 & - & 28.10 & 10.19 & \\
\hline & 4 & - & 14.93 & 40.26 & - & 27.00 & 11.07 & \\
\hline & 5 & - & 21.64 & 38.53 & - & 23.57 & 9.13 & \\
\hline & 6 & - & 16.34 & 40.95 & - & 26.49 & 10.13 & \\
\hline \multirow{6}{*}{ Cem ent } & 1 & - & - & 47.8 & - & 10.59 & 1. 34 & $\mathrm{Fe}_{2} \mathrm{O}_{3}<3.7$ \\
\hline & 2 & - & - & 47.7 & - & 11.55 & 1.98 & $\mathrm{SO}_{3} \mathrm{Tr}$ \\
\hline & 3 & - & - & 44.8 & - & 12.80 & 3.85 & $\mathrm{MgO}<1.0$ \\
\hline & 4 & - & - & 44.4 & - & 13.09 & 2.98 & \\
\hline & 5 & - & - & 42.3 & - & 15.01 & 4.18 & \\
\hline & 6 & - & - & 40.0 & - & 17.08 & 5.18 & \\
\hline
\end{tabular}

Table 2. Experimental condition.

$\mathrm{X}$-Ray tube anode: $\mathrm{W}$

Voltage: $40 \mathrm{kV}$

Current: $40 \mathrm{~mA}$
Integration: $133 \mathrm{sec}$ Total counts of monitor: 320,000 counts

\begin{tabular}{|c|c|c|c|c|c|c|c|c|c|c|c|c|}
\hline \multicolumn{2}{|c|}{ Line } & $\begin{array}{l}\mathrm{PbL} \alpha \\
\text { (Mo- } \\
\text { nitor) }\end{array}$ & $\mathrm{FeK} \alpha$ & $\operatorname{MnK} \alpha$ & $\mathrm{CaK} \alpha$ & $\mathrm{PK} \alpha$ & $\operatorname{SiK} \alpha \mathrm{A})$ & $\operatorname{SiK} \alpha \mathrm{B})$ & $\mathrm{SiK} \alpha \mathrm{C})$ & $\mathrm{AlK} \alpha \mathrm{A})$ & $\mathrm{AlK} \alpha \mathrm{B})$ & $\operatorname{AlK} \alpha \mathrm{C})$ \\
\hline \multicolumn{2}{|c|}{ Analyzing Crystal } & $\mathrm{LiF}$ & $\mathrm{LiF}$ & $\mathrm{LiF}$ & $\mathrm{LiF}$ & $\mathrm{EDdT}$ & Gypsum & Gypsum & Gypsum & Gypsum & Gypsum & Gypsum \\
\hline \multicolumn{2}{|c|}{ Detector } & S.D. & G.M. & G.M. & G.F. & G.F. & G.F. & G.F. & G.F. & G.F. & G.F. & G.F. \\
\hline \multicolumn{2}{|c|}{ Detector H.V. } & $850 \mathrm{~V}$ & $1500 \mathrm{~V}$ & $1500 \mathrm{~V}$ & $1650 \mathrm{~V}$ & $1750 \mathrm{~V}$ & $1800 \mathrm{~V}$ & $1800 \mathrm{~V}$ & $1800 \mathrm{~V}$ & $1850 \mathrm{~V}$ & $1850 \mathrm{~V}$ & $1850 \mathrm{~V}$ \\
\hline \multicolumn{2}{|c|}{ Soller slit } & $12^{\prime}$ & $12^{\prime}$ & $12^{\prime}$ & $12^{\prime}$ & $40^{\prime}$ & $40^{\prime}$ & $40^{\prime}$ & $40^{\prime}$ & $40^{\prime}$ & $40^{\prime}$ & $40^{\prime}$ \\
\hline \multirow{3}{*}{ 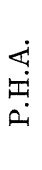 } & Base line & $8 \mathrm{~V}$ & - & - & $15 \mathrm{~V}$ & $7 \mathrm{~V}$ & $6 \mathrm{~V}$ & $5 \mathrm{~V}$ & $5 \mathrm{~V}$ & $7 \mathrm{~V}$ & $6 \mathrm{~V}$ & $5 \mathrm{~V}$ \\
\hline & Window & $\infty$ & - & - & $10 \mathrm{~V}$ & $6 \mathrm{~V}$ & $4 \mathrm{~V}$ & $10 \mathrm{~V}$ & $10 \mathrm{~V}$ & $6 \mathrm{~V}$ & $4 \mathrm{~V}$ & $10 \mathrm{~V}$ \\
\hline & $\begin{array}{l}\text { Pulse height } \\
\text { (approx.) }\end{array}$ & $20 \mathrm{~V}$ & - & - & $20 \mathrm{~V}$ & $10 \mathrm{~V}$ & $8 \mathrm{~V}$ & $10 \mathrm{~V}$ & $10 \mathrm{~V}$ & $10 \mathrm{~V}$ & $8 \mathrm{~V}$ & $10 \mathrm{~V}$ \\
\hline \multicolumn{2}{|c|}{ Filter } & Used & Used & Used & $\begin{array}{l}\text { Not } \\
\text { used }\end{array}$ & $\begin{array}{l}\text { Not } \\
\text { used }\end{array}$ & $\begin{array}{l}\text { Not } \\
\text { used }\end{array}$ & $\begin{array}{l}\text { Not } \\
\text { used }\end{array}$ & $\begin{array}{l}\text { Not } \\
\text { used }\end{array}$ & $\begin{array}{l}\text { Not } \\
\text { used }\end{array}$ & $\begin{array}{l}\text { Not } \\
\text { used }\end{array}$ & $\begin{array}{l}\text { Not } \\
\text { used }\end{array}$ \\
\hline \multicolumn{2}{|c|}{ Atomosphere } & Air & Air & Air & $\mathrm{H}_{2}$ & $\mathrm{H}_{2}$ & $\mathrm{H}_{2}$ & $\mathrm{H}_{2}$ & $\mathrm{H}_{2}$ & $\mathrm{H}_{2}$ & $\mathrm{H}_{2}$ & $\mathrm{H}_{2}$ \\
\hline
\end{tabular}

Remarks:
A): Slag A
B): Slag B
C): Slag C

G.M.: Geiger Müller Detector

S.D.: Scintillation Detector

G.F.: Gas Flow Proportional Detector

P.H.A.: Pulse Height Analyzer 
る(5)6). その中もつともいちじるしいのが，重元素の高 次線による妨害である.ことにスラッグなどのような比 較的重元素が多く存在する試料では，高次線とはいえか なりの強度を持つている。

この影響の除去には, ソーラースリットの分解能を高 め所要の軽元素のピークより重元素の高次線を分離させ る方法と, 波高分析により重元素の高次線をカットする 方法が考えられるが，一般に前者汪軽元素の回折線強度 を低下させるので適当ではなく，本実験では Table 2 に示すごとく, むしろ軽元素測定用のソーラースリット の開き角を大にしてX線強度を大にし，波高分析装置で カットする方法它採つた。

波高分析の条件設定には, $\mathrm{CaO}, \mathrm{P}_{2} \mathrm{O}_{5}$, 金属 $\mathrm{Si}$, 金属
Al などを使用し，それぞれについてパルス波高分布曲 線を求め, 最も適当な比例増幅器利得, 波高分析ベース 電圧，ウインドウ幅を選えだ. 波高分析のウインドウ幅 は普通小にとる程重元素の影響が除去され，同時にピー ク対バックグランウンド比もよくなるが，それに反し所 要の軽元素のピーク強度が落ち, 積分時間を一定にした 場合統計数率が減少し，それに伴い統計変動誤差が増大 する。乙たがつて，各試料について最適のウインドウ幅 を決定する必要がある. Table 2 の条件注予備実験によ り設定された最適の值である.

\section{3 実験方法}

実際試料を分析するに先立ち，あらかじめ重元素の軽 元素に与える影響について考えなければならない，本実

Table 3. Disturbance of high order lines of heavy elements to $\mathrm{PK} \alpha, \operatorname{SiK} \alpha, \operatorname{AlK} \alpha$.

\begin{tabular}{|c|c|c|c|c|c|c|c|}
\hline Element & & $\mathrm{Ca}$ & $\mathrm{P}$ & $\mathrm{Fe}$ & $\mathrm{Si}$ & $\mathrm{Mn}$ & $\mathrm{Al}$ \\
\hline Line & & $\mathrm{K} \beta$ & $\mathrm{K} \alpha$ & $\mathrm{K} \beta$ & $\mathrm{K} \alpha$ & $\mathrm{K} \alpha$ & $\mathrm{K} \alpha$ \\
\hline Wavelength ${ }^{(1)}$ & $\lambda(\AA)$ & 3.089 & 6.155 & 1.757 & 7.125 & 2.102 & 8.338 \\
\hline \multirow[t]{2}{*}{ Order } & $\mathrm{n}$ & 2 & 1 & 4 & 1 & 4 & 1 \\
\hline & $\mathrm{n} \lambda$ & 6.178 & 6.155 & 7.028 & 7.125 & 8.408 & 8.338 \\
\hline Bragg's angle & $2 \theta^{\circ}$ & 89.08 & 88.66 & 55.39 & 56.14 & 67.57 & 66.93 \\
\hline Analyzing Xtal & & \multicolumn{2}{|c|}{ EDDT } & \multicolumn{2}{|c|}{ Gypsum } & \multicolumn{2}{|c|}{ Gypsum } \\
\hline Energy $^{(2)}$ & $\mathrm{E}(\mathrm{KeV})$ & 4. 012 & 2.015 & 7.057 & 1.740 & 5.898 & 1. 487 \\
\hline
\end{tabular}

(1) Maurice C. Powers: X-ray Fluorescent Spectrometer Conversion Tables (1960)

(2) S. Fine and C.F. Hendee: Nucleonics 13, 37 (1955)

験での試料については，こ虫らの影響として FeK $\beta(n$ $=4)$ SiK $\alpha$ に与える妨害, $\operatorname{CaK} \beta(\mathrm{n}=2)$ の $\mathrm{PK} \alpha$ に与える妨害, $\operatorname{MnK} \alpha(\mathrm{n}=4)$ の $\mathrm{AlK} \alpha$ に与える妨害 および重元素による励起, 吸収効果などが考えられる.

Table 3 法これら重元素の高次線が軽元素の1次線を妨 害する様子学示したものである。

著者ら悢, 走査式ゴニオメータを用いて分析元素のピ ークプロフアイリングを行ない, あらかじあこれらの影 響を知ることができた。

Fig. 4 は SiK $\alpha$ に対する $\operatorname{FeK} \beta(n=4)$ の影響を見 るため, Slag A No. 1 ( $\mathrm{Fe} \mathrm{29.5 \% ,} \mathrm{SiO}_{2} 9.67 \%$ ) の 試料を選び，波高分析のウインドウ幅 (W) 䘮 $\infty$ およ

5) L.S. Birks: "X-ray Spectrochemical Analysis" p. 64 (1959) (Interscience Publishers, Inc., New York).

6) Jacob Sherman: "Advances in X-ray Analysis" Volume 1, p. 240 (1957).

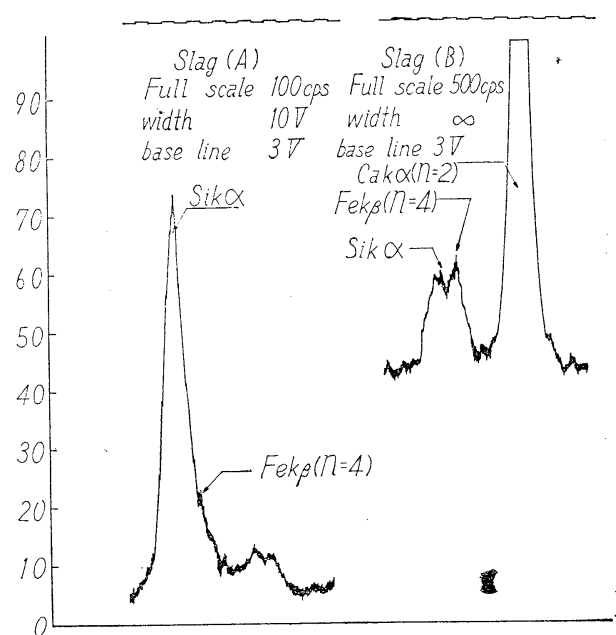

Fig. 4. Peak profiling example of the sample (Slag A). 
び $10 \mathrm{~V}$ に設定してピークプロフアイリングを行なつた ものである・

Fig. 4 で見られるように $W=\infty$ の場合では, 最初予 想されたように FeK $\beta(\mathrm{n}=4)$ が $\mathrm{SiK} \alpha$ をいちじるし く妨害し, しかも重元素の散乱 X線のためバックグラウ ンドが相当高く，ピーク詨バックグラウンド比はかなり 覀い. しかしながら $W=10 \mathrm{~V}$ の場合では $\mathrm{FeK} \beta(\mathrm{n}=$ 4) の妨害もほとえどなくなり，バックグラウンドもず つと低くなつている. 実際の測定には $W=4 V$ を選び, ピーク詨バックグラウンド比約 30 を得た.

一方セメントのように $\mathrm{Fe}$ の少ない試料では, $W=$ $10 V$ で $\operatorname{FeK} \beta(\mathrm{n}=4)$ の妨害壮全く見られなかつた. かようにして $\mathrm{PK} \alpha$ に対する $\mathrm{CaK} \beta(\mathrm{n}=2)$ の妨害, $\mathrm{AlK} \alpha$ に対する $\mathrm{MnK} \alpha(\mathrm{n}=4)$ の妨害はほとえど取り 除くことができた．このようにして前記試料の各元素に つき以上の条件で測定し, 検量線它描いて精度検討を行 なつた. 精度検討の方法は以下のごとくである.

一般にある試料中のある元素を測定した場合, 得られ た分析值には種々の誤差が含まれている，この誤差とし て考えられるおもなものには

(1) 統計変動による誤差

(2) 装置固有の誤差

(3) 他元素の妨害による誤差

(4) 化学分析値による䛊差

（5）試料作成法による誤差

(6) 測定操作による誤差

などがあげられる・これらの䛊差が結局分析值の精度を 左右しているわけである.この中，他元素の妨害による 誤差としては, 前記のピークの重なりのほかマトリック スの励起, 吸収効果があり, これらについて従来より種 々の補正法7)81 が考えられかなりの効果が発表されてい るが，いずれも日常分析に際しては補正を行なうことは 容易でない。また統計変動による誤差注統計数率を大に とればそれだけ減少するが，実際の場合 $\mathrm{Al}, \mathrm{Si}$ などの 軽元素については大なるX線強度を得ることが難かし く, 分析時間を長くとるより方法がないが，迅速分析で はこれが許されない。

かような理由で著者らはこれらの誤差全部を含めた場 合の分析精度につき検討を行なつた。

先ず各試料中の各元素につきそれぞれ検量線を作成 乙, 測定值と化学分析值との差 $\Delta$ を求め標準偏差 $\delta_{1}$ を

7) H.D. Burnham, John Hower and L.C. Johnes: Anal. Chem., 29, 1827 (1957).

8) 桃木: 分析化学, 10, 1058 (1961).
算出し, この場合の分析精度とした. $\delta_{1}$ は実際分折の精 度であり，この中に湔記の誤差が含まれている.

また一方これらの種々の誤差の中, 統計変動誤差と装 置固有の誤差以外の誤差が何らかの方法により全部除去 されたと仮定した場合の誤差，すなわち積分時間を一定 にし前記の条件で測定する場合, 理論的に期待し得る最 高精度 $\delta_{2}$ を求め $\delta_{1}$ との比較を行ない, 他の誤差の大き さ它知つた。

$\delta_{2}$ を求めるに際しては次の方法をとつた. すなわら, スラッグ $\mathrm{A}$, スラッグ $\mathrm{B}$, セメントの各試料につきそれ ぞれ最低化学分析濃度の試料を選び，それぞれ 10 回の 測定を行ない，測定值の読みの標準偏差 $\delta_{I}$ を求め，検 量線の公配 $\tan \theta$ を用いて化学分析濃度としての標準偏 差 $\delta_{2}$ に換算した.すなわち,

$$
\delta_{2}=\delta_{I} / \tan \theta
$$

の関係がある。

ここで $\delta_{I}$ 学求めるに際して, 各元素の最低化学分析 濃度のものを選えだ理由は, 積分時間一定の同時分析で あるため統計変動誤差が一番大であると考えたからであ る.

\section{4. 実験結果および検討}

スラッグおよびセメントについて得られた各成分の検 量線を Fig. 5〜Fig. 17 に示す.

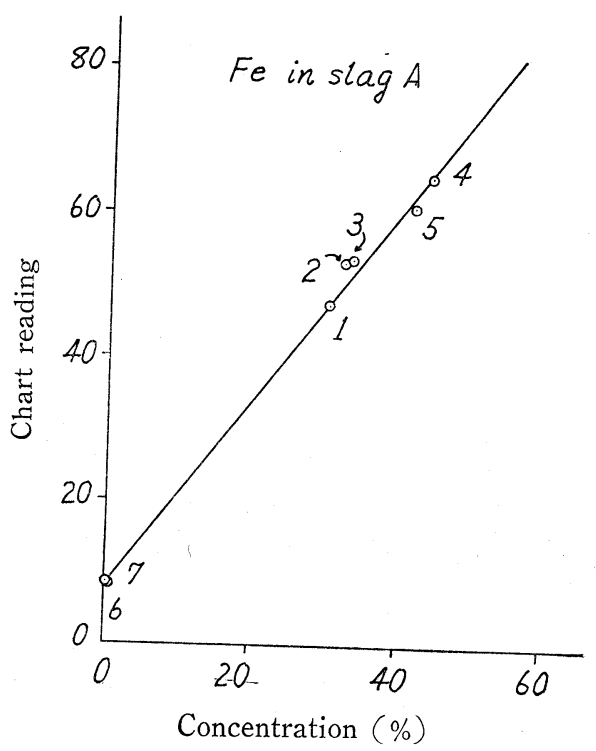

Fig. 5. Working curve for the determination of $\mathrm{T} F e$ in Slag A. 


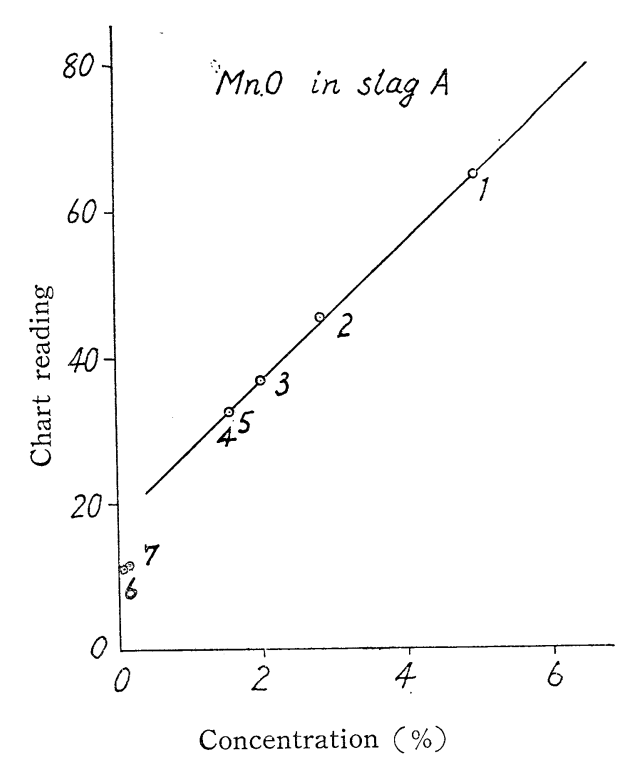

Fig. 6. Working curve for the determination of $\mathrm{MnO}$ in Slag A.

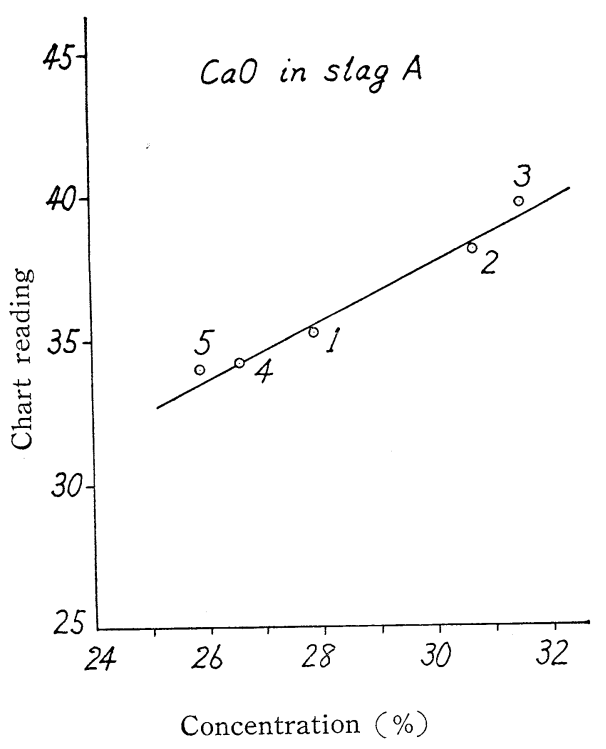

Fig. 7. Working curve for the determination of $\mathrm{CaO}$ in Slag A.

スラッグ Aの各検量線について考えると， Fe はかな り広い浱度範囲にわたり大きなバラッキはみられない が， MnO では No. 6, No. 7 の 2 点が特に低く測定さ れている.この原因については不明である.

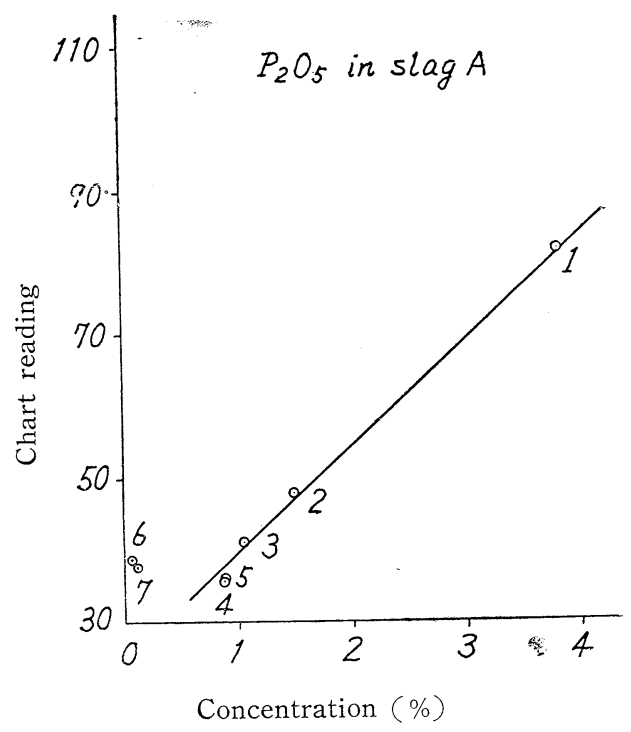

Fig. 8. Working curve for the determination of $\mathrm{P}_{2} \mathrm{O}_{5}$ in Slag $\mathrm{A}$.

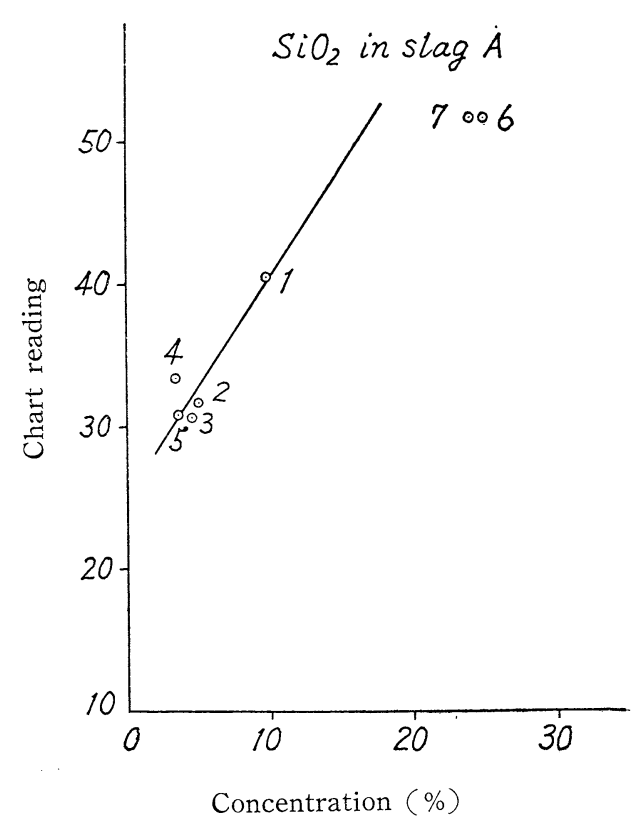

Fig. 9. Working curve for the determination of $\mathrm{SiO}_{2}$ in Slag $\mathrm{A}$.

また $\mathrm{P}_{2} \mathrm{O}_{5}, \mathrm{SiO}_{2}$ についても No. 6, No. 7 の 2 点に 大きなバラッキが見られるのは, 重元素による励起効果 よりさしろ, 前記の高次線による妨害が大きく影響して いると考光る方が妥当である. すなわち $\mathrm{P}_{2} \mathrm{O}_{5}$ におい心 


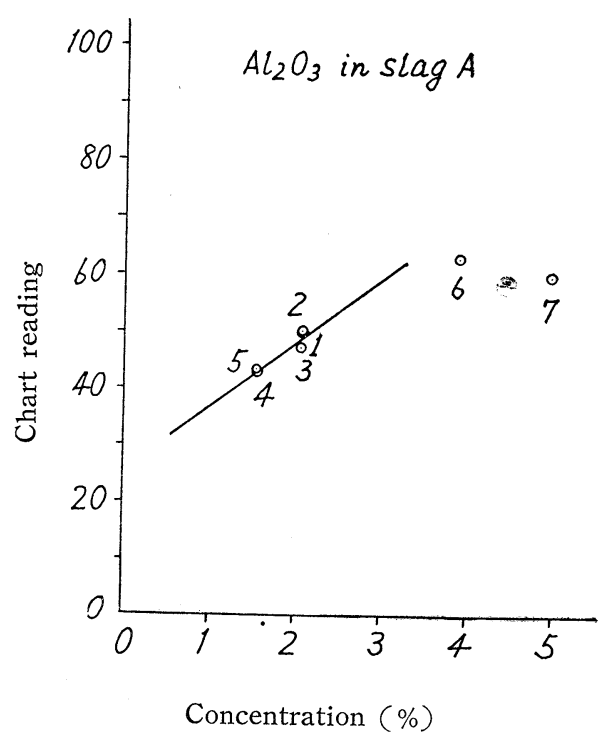

Fig. 10. Working curve for the determination of $\mathrm{Al}_{2} \mathrm{O}_{3}$ in Slag $\mathrm{A}$.

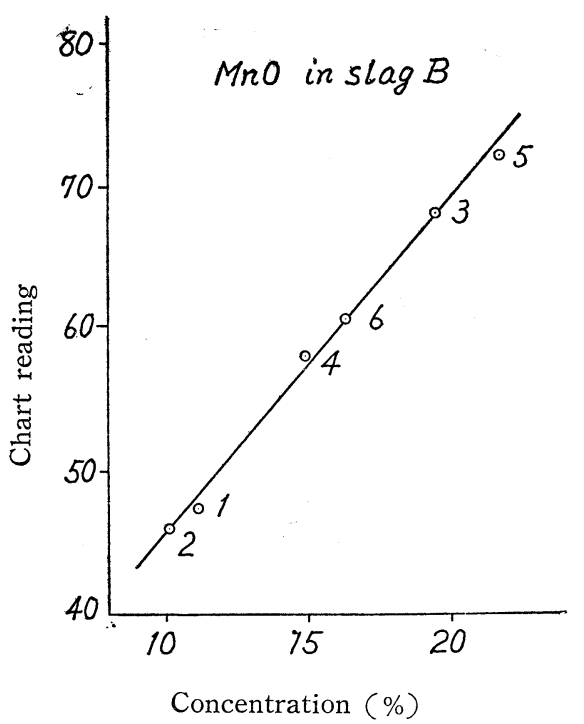

Fig. 11. Working curve for the determination of $\mathrm{MnO}$ in Slag B.

は $\mathrm{CaO}$ が特に多いので高く測定され， $\mathrm{SiO}_{2}$ において は Fe が特に少ないため低く測定されたものである。な お， $\mathrm{Al}_{2} \mathrm{O}_{3}$ の場合にも同様の傾向が見られるが，この場 合は $\operatorname{MnK} \alpha(\mathrm{n}=4)$ の影響と同程度に Fe による励起 効果が原因していると思われる.

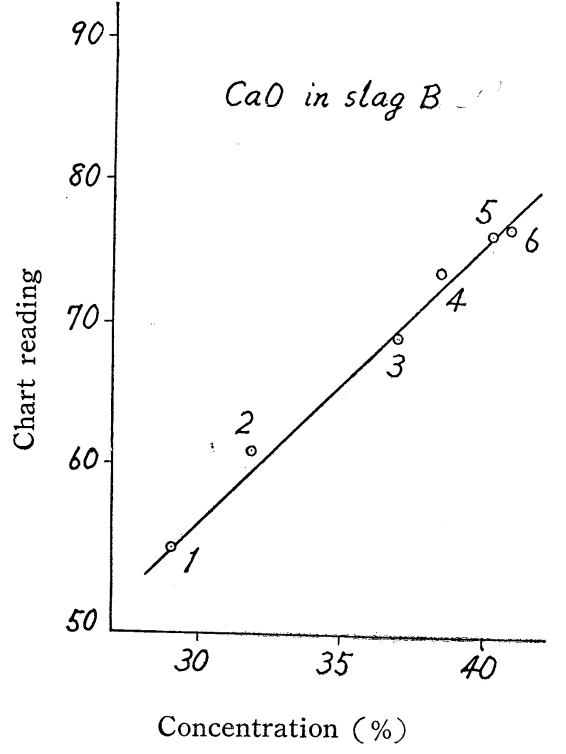

Fig. 12. Working curve for the determination of $\mathrm{CaO}$ in Slag $\mathrm{B}$.

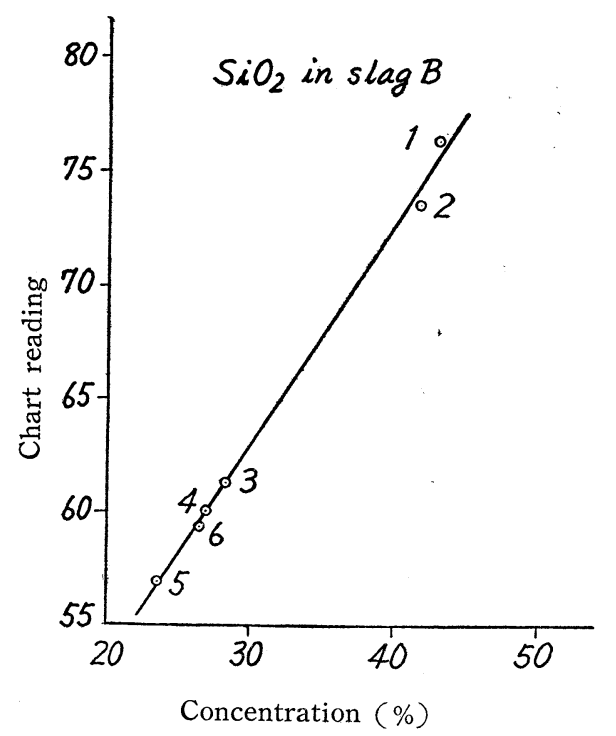

Fig. 13. Working curve for the determination of $\mathrm{SiO}_{2}$ in Slag $\mathrm{B}$.

このように重元素の化学濃度が極端に変化している試 料中の軽元素を測定する場合には検量線を别に作成する 必要がある。

スラッグBについて上記の事柄を考察すると，この試 料では重元素として $\mathrm{MnO}$ が多量に存在しているが, 各 


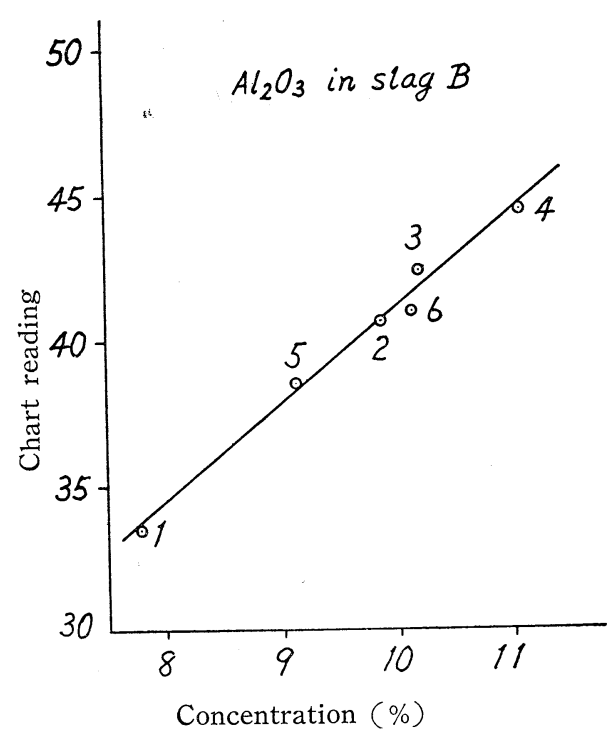

Fig. 14. Working curve for the determination of $\mathrm{Al}_{2} \mathrm{O}_{3}$ in Slag $\mathrm{B}$.

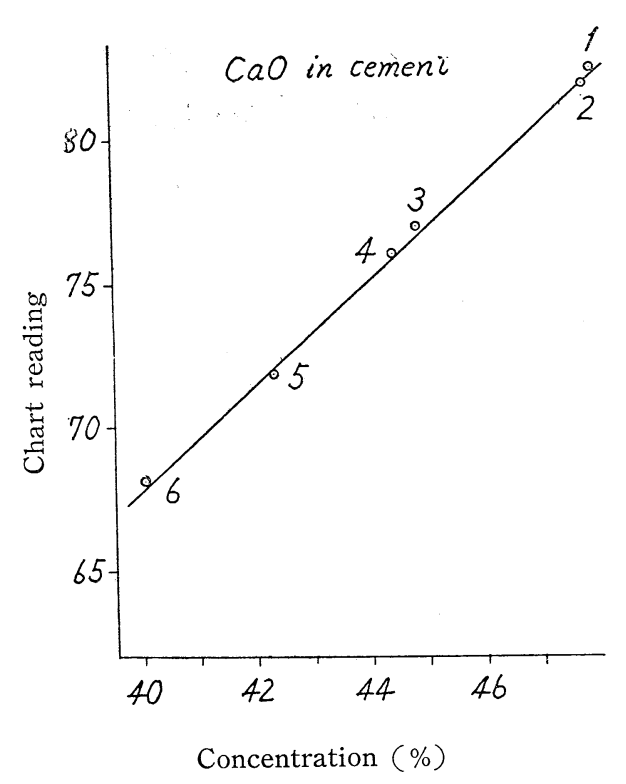

Fig. 15. Working curve for the determination of $\mathrm{CaO}$ in Cement.

試料については化学濃度の変化がスラッグ $\mathrm{A}$ に較べて小 さく, ことにスラッグ A No. 6, No. 7 のような 極端に重元素の化学濃度の变化する試料がないので, $\mathrm{SiO}_{2}, \mathrm{Al}_{2} \mathrm{O}_{3}$ いずれの検量線についても直接の影響は現 われていない.ことに $\mathrm{Al}_{2} \mathrm{O}_{3}$ の場合, 波高分析のウイ

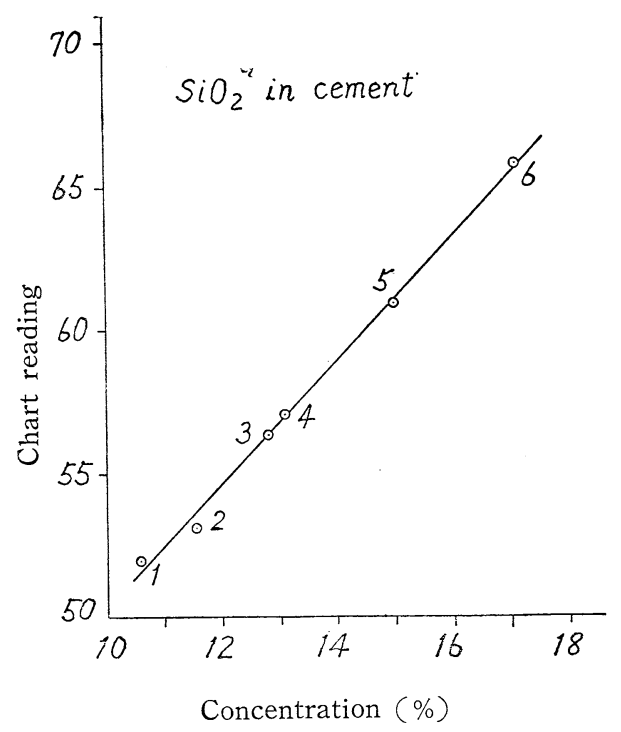

Fig. 16. Working curve for the determination of $\mathrm{SiO}_{2}$ in Cement.

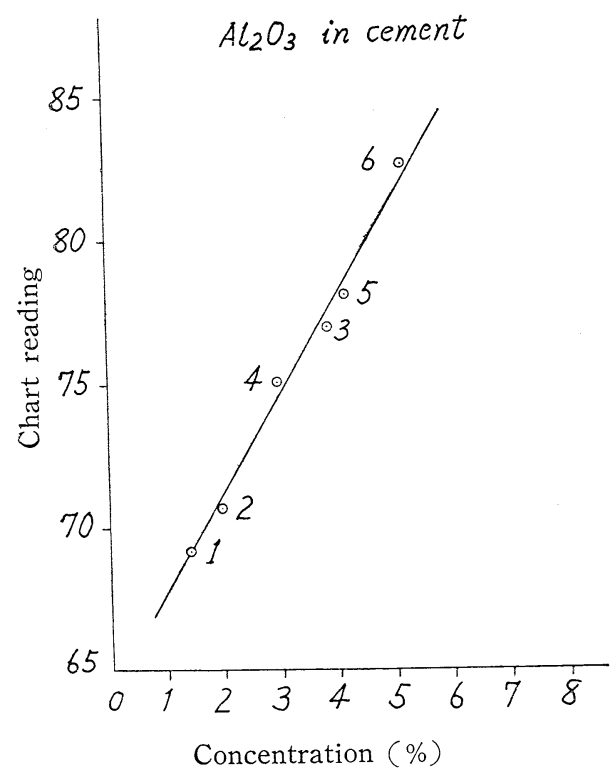

Fig. 17. Working curve for the determination of $\mathrm{Al}_{2} \mathrm{O}_{3}$ in Cement.

ンドウ幅も大きく, スラッグ $\mathrm{A}$ の場合以上に $\mathrm{AlK} \alpha$ に 対する $\mathrm{MnK} \alpha(\mathrm{n}=4)$ の妨害が大きいはずであるが， その影響が全然見られないのは注目すべきことである。

同様にセメントの場合にも, 重元素としては $\mathrm{Fe}_{2} \mathrm{O}_{3}$ が存在するだけでしかも濃度変化が少ないため, $\mathrm{SiO}_{2}$, 
$\mathrm{Al}_{2} \mathrm{O}_{3}$ ともかなりよい検量線が得られている.

Table $4 \sim$ Table 8 に本実験で得られた分析值と化学 分析值の比較定示すとともに算出した分析精度 $\delta_{1}$ の值 を示す. $\delta_{1}$ の算出に際しては，スラッグ A No. 6, No. 7 中の $\mathrm{MnO}, \mathrm{P}_{2} \mathrm{O}_{5}, \mathrm{SiO}_{2}, \mathrm{Al}_{2} \mathrm{O}_{3}$ のように重元素の影 響究いちじるしく受け同一検量線では表わすことのでき ない点は除外して計算した.
Table 9 はスラッグ A，スラッグ B セメント中の各成 分に対しもつとも化学濃度の低い試料をえらびおのおの 10 回の測定を行ない, その平均值を $I_{\text {mean }}$ とし, 読み の標準偏差 $\delta_{I}$ を求め, 実験で得られた検量線の公配より 理論的に期待される最低限度の精度 $\delta_{2}$ 岩算出したもの である.また同時に読みの変動係数 $\sigma_{\mathrm{obs}}$. と統計変動係 数 $\sigma_{\mathrm{cal}}$. との比較を示した。積分時間は, 検量線作成の

Table 4. Results of the determination of $\mathrm{T}$. Fe, $\mathrm{MnO}$ and $\mathrm{CaO}$ in slag $\mathrm{A}$.

\begin{tabular}{|c|c|c|c|c|c|c|c|c|c|}
\hline \multirow{2}{*}{$\begin{array}{c}\text { Sample } \\
\text { No. }\end{array}$} & \multicolumn{3}{|c|}{ T. Fe in slag $A$} & \multicolumn{3}{|c|}{$\mathrm{MnO}$ in slag $\mathrm{A}$} & \multicolumn{3}{|c|}{$\mathrm{CaO}$ in slag $\mathrm{A}$} \\
\hline & $\begin{array}{l}\text { chemi. } \\
\text { analy. }\end{array}$ & $\begin{array}{l}\text { X.Q. } \\
\text { analy. }\end{array}$ & diff. $\Delta$ & $\begin{array}{l}\text { chemi. } \\
\text { analy. }\end{array}$ & $\begin{array}{l}\text { X.Q. } \\
\text { analy. }\end{array}$ & diff. $\Delta$ & $\begin{array}{l}\text { chemi. } \\
\text { analy. }\end{array}$ & $\begin{array}{l}\text { X.Q. } \\
\text { analy. }\end{array}$ & diff. $\Delta$ \\
\hline 1 & 29.5 & 29.5 & 0.0 & 4.96 & 4.96 & 0.00 & 27.9 & 27.8 & 0.1 \\
\hline 2 & 32.1 & 33.8 & 1.7 & 2.83 & 2.87 & 0.04 & 30.7 & 30.4 & 0.3 \\
\hline 3 & 33.1 & 34.3 & 1.2 & 2.05 & 2.03 & 0.02 & 31.7 & 31.85 & 0.15 \\
\hline 4 & 43.9 & 42.9 & 1.0 & 1.55 & 1.51 & 0.04 & 26.6 & 26.7 & 0.1 \\
\hline 5 & 41.6 & 40.8 & 0.8 & 1.55 & 1.54 & 0.01 & 25.9 & 26.6 & 0.7 \\
\hline 6 & 0.5 & 0.5 & 0.0 & 0.11 & - & - & 57.2 & - & - \\
\hline 7 & 0.6 & 0.3 & 0.3 & 0.14 & 一 & 一 & 58.8 & - & - \\
\hline$\delta_{1}$ & \multicolumn{3}{|c|}{$1.0 \%$} & \multicolumn{3}{|c|}{$0.02 \%$} & \multicolumn{3}{|c|}{$0.4 \%$} \\
\hline
\end{tabular}

Table 5. Results of the determination of $\mathrm{P}_{2} \mathrm{O}_{5}, \mathrm{SiO}_{2}$ and $\mathrm{Al}_{2} \mathrm{O}_{3}$ in slag $\mathrm{A}$.

\begin{tabular}{|c|c|c|c|c|c|c|c|c|c|}
\hline \multirow{2}{*}{$\begin{array}{c}\text { Sample } \\
\text { No. }\end{array}$} & \multicolumn{3}{|c|}{$\mathrm{P}_{2} \mathrm{O}_{5}$ in slag $\mathrm{A}$} & \multicolumn{3}{|c|}{$\mathrm{SiO}_{2}$ in slag $\mathrm{A}$} & \multicolumn{3}{|c|}{$\mathrm{Al}_{2} \mathrm{O}_{3}$ in slag $\mathrm{A}$} \\
\hline & $\begin{array}{l}\text { chemi. } \\
\text { analy. }\end{array}$ & $\begin{array}{c}\text { X.Q. } \\
\text { analy. }\end{array}$ & diff. $\Delta$ & $\begin{array}{l}\text { chemi. } \\
\text { analy. }\end{array}$ & $\begin{array}{l}\text { X.Q. } \\
\text { analy. }\end{array}$ & diff. $\Delta$ & $\begin{array}{l}\text { chemi. } \\
\text { analy. }\end{array}$ & $\begin{array}{c}\text { X.Q. } \\
\text { analy. }\end{array}$ & diff. $\Delta$ \\
\hline 1 & 3.80 & 3.85 & 0.05 & 9.76 & 9.76 & 0.0 & 2.06 & 2.16 & 0.1 \\
\hline 2 & 1.51 & 1.58 & 0.07 & 5.00 & 4.10 & 0.9 & 2.06 & 2.16 & 0.1 \\
\hline 3 & 1.06 & 1.07 & 0.05 & 4.50 & 3.50 & 1.0 & 2.06 & 1.91 & 0.15 \\
\hline 4 & 0.88 & 0.78 & 0.10 & 3.40 & 5.40 & 2.0 & 1.54 & 1. 49 & 0.05 \\
\hline 5 & 0.89 & 0.79 & 0.10 & 3.56 & 3.56 & 0.0 & 1.54 & 1.59 & 0.05 \\
\hline$\delta_{1}$ & \multicolumn{3}{|c|}{$0.08 \%$} & \multicolumn{3}{|c|}{$1.2 \%$} & \multicolumn{3}{|c|}{$0.1 \%$} \\
\hline
\end{tabular}

Table 6. Results of the determination of $\mathrm{MnO}, \mathrm{CaO}$ and $\mathrm{SiO}_{2}$ in slag $\mathrm{B}$.

\begin{tabular}{|c|c|c|c|c|c|c|c|c|c|}
\hline \multirow{2}{*}{$\begin{array}{c}\text { Sample } \\
\text { No. }\end{array}$} & \multicolumn{3}{|c|}{$\mathrm{MnO}$ in slag $\mathrm{B}$} & \multicolumn{3}{|c|}{$\mathrm{CaO}$ in slag $\mathrm{B}$} & \multicolumn{3}{|c|}{$\mathrm{SiO}_{2}$ in slag $\mathrm{B}$} \\
\hline & $\begin{array}{l}\text { chemi. } \\
\text { analy. }\end{array}$ & $\begin{array}{c}\text { X.Q. } \\
\text { analy. }\end{array}$ & diff. $\Delta$ & $\begin{array}{l}\text { chemi. } \\
\text { analy. }\end{array}$ & $\begin{array}{c}\text { X.Q. } \\
\text { analy. }\end{array}$ & diff. $A$ & $\begin{array}{l}\text { chemi. } \\
\text { analy. }\end{array}$ & $\begin{array}{c}\text { X.Q. } \\
\text { analy. }\end{array}$ & diff. $\Delta$ \\
\hline 1 & 11.18 & 10.75 & 0.43 & 29.13 & 29.15 & 0.0 & 42.82 & 43.4 & 0.6 \\
\hline 2 & 10.12 & 10.12 & 0.0 & 31.92 & 32.65 & 0.7 & 40.16 & 39.2 & 1.0 \\
\hline 3 & 19.38 & 19.38 & 0.0 & 36.98 & 36.75 & 0.2 & 28.10 & 28.0 & 0.1 \\
\hline 4 & 14.93 & 15.2 & 0.17 & 40.26 & 40.35 & 0.1 & 27.00 & 27.1 & 0.1 \\
\hline 5 & 21.64 & 21.6 & 0.04 & 38.53 & 39.1 & 0.5 & 23.57 & 23.8 & 0.2 \\
\hline 6 & 16.34 & 16.34 & 0.0 & 40.95 & 40.65 & 0.3 & 26.49 & 26.3 & 0.2 \\
\hline$\delta_{1}$ & \multicolumn{3}{|c|}{$0.21 \%$} & \multicolumn{3}{|c|}{$0.4 \%$} & \multicolumn{3}{|c|}{$0.2 \%$} \\
\hline
\end{tabular}


Table 7. Results of the determination of $\mathrm{Al}_{2} \mathrm{O}_{3}$ in slag $\mathrm{B}$ and $\mathrm{CaO}, \mathrm{SiO}_{2}$ in cement.

\begin{tabular}{|c|c|c|c|c|c|c|c|c|c|}
\hline \multirow{2}{*}{$\begin{array}{c}\text { Sample } \\
\text { No. }\end{array}$} & \multicolumn{3}{|c|}{$\mathrm{Al}_{2} \mathrm{O}_{3}$ in slag $\mathrm{B}$} & \multicolumn{3}{|c|}{$\mathrm{CaO}$ in cement $\mathrm{B}$} & \multicolumn{3}{|c|}{$\mathrm{SiO}_{2}$ in cement } \\
\hline & $\begin{array}{l}\text { chemi. } \\
\text { analy. }\end{array}$ & $\begin{array}{c}\mathrm{X} . \mathrm{Q} . \\
\text { analy. }\end{array}$ & diff. $\Delta$ & $\begin{array}{l}\text { chemi. } \\
\text { analy. }\end{array}$ & $\begin{array}{c}\text { X.Q. } \\
\text { analy. }\end{array}$ & diff. $\Delta$ & $\begin{array}{l}\text { chemi. } \\
\text { analy. }\end{array}$ & $\begin{array}{c}\text { X.Q. } \\
\text { analy. }\end{array}$ & diff. $\Delta$ \\
\hline 1 & 7.79 & 7.75 & 0.04 & 47.8 & 47.9 & 0.1 & 10.59 & 10.8 & 0.2 \\
\hline 2 & 7.86 & 7.84 & 0.02 & 47.7 & 47.65 & 0.05 & 11.55 & 11.3 & 0.25 \\
\hline 3 & 10.19 & 10.59 & 0.40 & 44.8 & 44.95 & 0.15 & 12.80 & 12.8 & 0.0 \\
\hline 4 & 11.07 & 10.97 & 0.10 & 44.4 & 44.4 & 0.0 & 13.09 & 13.15 & 0.05 \\
\hline 5 & 9.13 & 9.19 & 0.06 & 42.3 & 42.15 & 0.15 & 15.01 & 14.95 & 0.05 \\
\hline 6 & 10.13 & 9.78 & 0.35 & 40.0 & 40.15 & 0.15 & 17.08 & 17.2 & 0.1 \\
\hline$\delta_{1}$ & \multicolumn{3}{|c|}{$0.24 \%$} & \multicolumn{3}{|c|}{$0.13 \%$} & \multicolumn{3}{|c|}{$0.15 \%$} \\
\hline
\end{tabular}

Table 8. Results of the determination of $\mathrm{Al}_{2} \mathrm{O}_{3}$ in cement.

\begin{tabular}{c|c|c|c}
\hline \multirow{2}{*}{ Sample } & \multicolumn{3}{|c}{$\mathrm{Al}_{2} \mathrm{O}_{3}$ in cement } \\
\cline { 2 - 4 } No. & $\begin{array}{c}\text { chemi. } \\
\text { analy. }\end{array}$ & $\begin{array}{c}\text { X.Q. } \\
\text { analy. }\end{array}$ & diff. 4 \\
\hline 1 & 1.34 & 1.36 & 0.02 \\
2 & 1.98 & 1.88 & 0.10 \\
3 & 3.85 & 3.68 & 0.17 \\
4 & 2.98 & 3.18 & 0.20 \\
5 & 4.18 & 4.03 & 0.15 \\
6 & 5.18 & 5.35 & 0.17 \\
\hline$\delta_{1}$ & \multicolumn{3}{|c}{$0.16 \%$} \\
\hline
\end{tabular}

折 133 秒の積分で得られた 2 回の平均值を採用している ので，この場合 266 秒にした.

一般に $\sigma_{\mathrm{c} \text { al. }}$ は純粋な統計変動に基づく誤差である が， $\sigma_{\text {obs. }}$. の值は $\sigma_{\text {cal }}$. の值よりも大になることが予想 される。

Table 9 において $\sigma_{\text {cal }}$. と $\sigma_{\text {obs. }}$. を比較すると, 予想 通り $\sigma_{\text {obs }}$.の方がやや大きな值を示している. しかしそ の差は僅少である.乙たがつて $\sigma_{\text {obs. }}$ はほとえどが統計 変動に基づく誤差であり, 装置自体の誤差は考える必要 がない、なお Table 9 において， $\sigma_{\text {obs. }}$. の值が $\sigma_{\text {cal }}$. よ りもかえつて小さいものがあるが，これは $\sigma_{\mathrm{obs}}$.の算出 がわずか 10 回の繰り返し測定結果により行なわれてい るためで，さらに多くの繰り返し測定を行えば $\sigma_{\text {cal. }}$ よ

Table 9. Determination of the value of $\sigma_{\text {obs. }}, \sigma_{\text {cal }}$ and $\delta_{2}$ of each element.

Slag A

\begin{tabular}{c|c|c|c|c|c|c}
\hline \hline Element & T. Fe & $\mathrm{MnO}$ & $\mathrm{CaO}$ & $\mathrm{P}_{2} \mathrm{O}_{5}$ & $\mathrm{SiO}_{2}$ & $\mathrm{Al}_{2} \mathrm{O}_{3}$ \\
\hline Content & $0.5 \%$ & $1.55 \%$ & $25.9 \%$ & $0.88 \%$ & $3.40 \%$ & $1.54 \%$ \\
$I_{\text {mean }}$ & 35.54 & 32.13 & 35.99 & 35.58 & 33.40 & 42.74 \\
$\delta_{I}$ & 0.55 & 0.13 & 0.43 & 1.51 & 0.75 & 0.87 \\
$\sigma_{\text {obs. }}$ & $1.15 \%$ & $0.39 \%$ & $1.19 \%$ & $2.90 \%$ & $2.10 \%$ & $2.04 \%$ \\
$\sigma_{\text {cal. }}$ & $1.18 \%$ & $0.32 \%$ & $0.93 \%$ & $2.76 \%$ & $2.05 \%$ & $2.07 \%$ \\
$\delta_{2}$ & $0.42 \%$ & $0.01 \%$ & $0.44 \%$ & $0.09 \%$ & $0.5 \%$ & $0.07 \%$
\end{tabular}

Slag B

\begin{tabular}{c|c|c|c|c|c|c}
\hline \hline Element & T. Fe & $\mathrm{MnO}$ & $\mathrm{CaO}$ & $\mathrm{P}_{2} \mathrm{O}_{5}$ & $\mathrm{SiO}_{2}$ & $\mathrm{Al}_{2} \mathrm{O}_{3}$ \\
\hline Content & - & $10.12 \%$ & $29.13 \%$ & - & $23.57 \%$ & $7.79 \%$ \\
$I_{\text {mean }}$ & - & 46.00 & 54.15 & - & 56.90 & 33.49 \\
$\delta_{I}$ & - & 0.11 & 0.49 & - & 0.29 & 0.80 \\
$\sigma_{\text {obs. }}$ & - & $0.23 \%$ & $0.91 \%$ & - & $0.51 \%$ & $2.39 \%$ \\
$\delta_{\text {cal. }}$ & - & $0.20 \%$ & $0.85 \%$ & - & $0.48 \%$ & $2.15 \%$ \\
$\delta_{2}$ & - & $0.05 \%$ & $0.31 \%$ & - & $0.29 \%$ & $0.24 \%$ \\
\hline
\end{tabular}


Cement

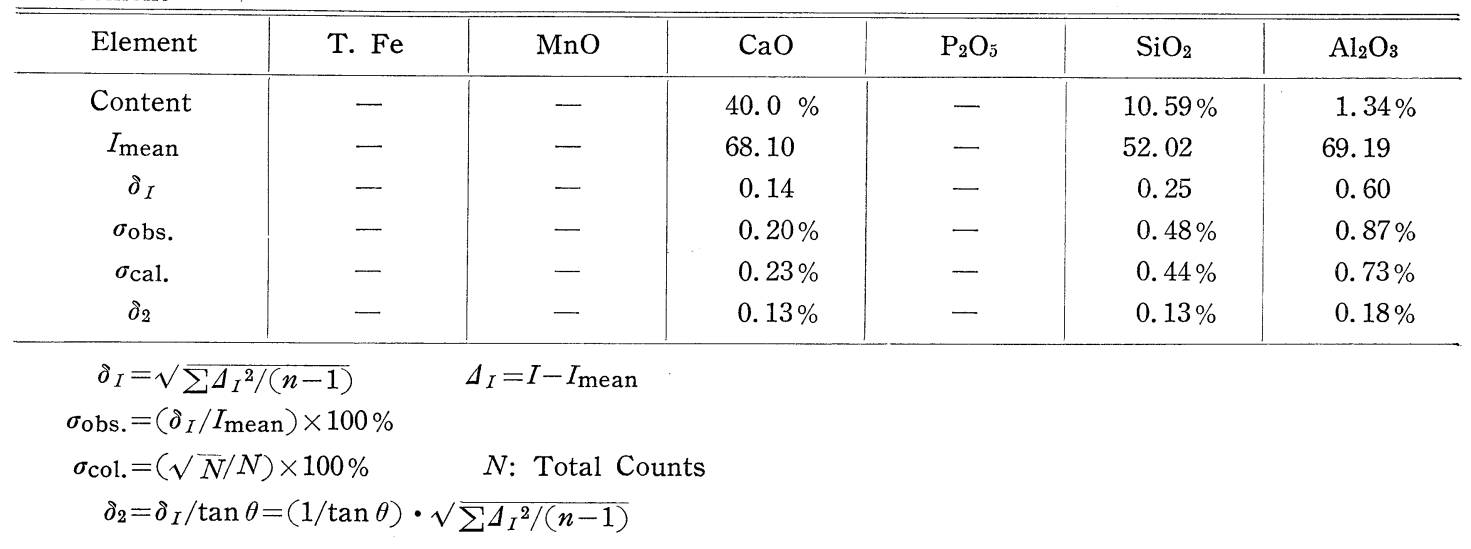

りも大になると考えられる。

また $\delta_{1}, \delta_{2}$ についていえば， $\delta_{2}$ は統計変動誤差に基 づくものであるが， $\delta_{1}$ は統計变動誤差のほかあらゆる誤 差に基づくものであり, 普通 $\delta_{2}$ に較べ $\delta_{1}$ の值は大にな
ることが予想される・

Table 10 は $\delta_{1}, \delta_{2}$ の比較をそれぞれの試料について 示したものであるが予想通り $\delta_{1}$ の方が大きい傾向にあ る.

Slag A

Table 10. Comparison between $\delta_{1}$ and $\delta_{2}$.

\begin{tabular}{c|c|c|c|c|c|c}
\hline \hline Element & T. Fe & $\mathrm{MnO}$ & $\mathrm{CaO}$ & $\mathrm{P}_{2} \mathrm{O}_{5}$ & $\mathrm{SiO}_{2}$ & $\mathrm{Al}_{2} \mathrm{O}_{3}$ \\
\hline Content range & $0.5 \sim 44 \%$ & $0.1 \sim 5 \%$ & $26 \sim 60 \%$ & $0.1 \sim 4 \%$ & $3.5 \sim 10 \%$ & $1.5 \sim 2 \%$ \\
$\delta_{1}$ & $1.0 \%$ & $0.02 \%$ & $0.4 \%$ & $0.08 \%$ & $1.2 \%$ & $0.1 \%$ \\
$\delta_{2}$ & $0.42 \%$ & $0.01 \%$ & $0.44 \%$ & $0.09 \%$ & $0.5 \%$ & $0.07 \%$ \\
\hline
\end{tabular}

Slag B

\begin{tabular}{c|c|c|c|c|c|c}
\hline \hline Element & T. Fe & $\mathrm{MnO}$ & $\mathrm{CaO}$ & $\mathrm{P}_{2} \mathrm{O}_{5}$ & $\mathrm{SiO}_{2}$ & $\mathrm{Al}_{2} \mathrm{O}_{3}$ \\
\hline Content range & - & $10 \sim 22 \%$ & $30 \sim 40 \%$ & - & $24 \sim 43 \%$ & $8 \sim 11 \%$ \\
$\delta_{1}$ & - & $0.21 \%$ & $0.4 \%$ & - & $0.2 \%$ & $0.24 \%$ \\
$\delta_{2}$ & - & $0.05 \%$ & $0.31 \%$ & - & $0.29 \%$ & $0.24 \%$ \\
\hline
\end{tabular}

\section{Cement}

\begin{tabular}{c|c|c|c|c|c|c}
\hline \hline Element & $\mathrm{T} . \mathrm{Fe}$ & $\mathrm{MnO}$ & $\mathrm{CaO}$ & $\mathrm{P}_{2} \mathrm{O}_{5}$ & $\mathrm{SiO}_{2}$ & $\mathrm{Al}_{2} \mathrm{O}_{3}$ \\
\hline Content range & - & - & $40 \sim 48 \%$ & - & $10 \sim 17 \%$ & $1.3 \sim 5.2 \%$ \\
$\delta_{1}$ & - & - & $0.13 \%$ & - & $0.15 \%$ & $0.16 \%$ \\
$\grave{\partial}_{2}$ & - & - & $0.13 \%$ & - & $0.13 \%$ & $0.18 \%$ \\
\hline
\end{tabular}

$\delta_{1}, \delta_{2}$ を比較した場合， $\delta_{2}$ に比して $\delta_{1}$ の值がかなり

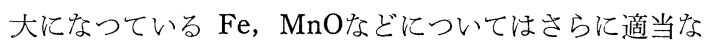
測定条件を選定する必要があると考元られるが， $\mathrm{Al}_{2} \mathrm{O}_{3}$ のように $\delta_{1}, \delta_{2}$ の值が近接しているものについては, 添ぼ理想的な分析が行なわれたことを意味している。ま た $\mathrm{SiO}_{2}$ に対しては, スラッグ $\mathrm{B}$, セメントでは理想的 な分析が行なわれているが，スラッグ $\mathrm{A}$ の場合では $\delta_{1}$
の值が $\boldsymbol{\delta}_{2}$ に較べて非常に大きくなつている．この原因 は化学分析精度に由来すると考えるよりもむしろ他の試 料に較べ $\operatorname{SiK} \alpha$ がとくに $\operatorname{FeK} \beta(n=4)$ の影響を大き く受けるためと考える方が妥当であろう.

以上の結果をすでに報告されたもの1/2)3/4) と比較する と, 成分に多少の相違はあるが大体同程度の精度が得ら れており，たとえばセメント中の $\mathrm{SiO}_{2}, \mathrm{Al}_{2} \mathrm{O}_{3}$ の例を 
とれば，内川・猪股両氏の報告2)されている 20〜22\% $\mathrm{SiO}_{2}$ に対する $0.17 \%, 4 \sim 6 \% \mathrm{Al}_{2} \mathrm{O}_{3}$ に対する $0.2 \%$,

George andermann 他 2 氏の 報告3) されている 19〜23 $\% \mathrm{SiO}_{2}$ に対守る $0.5 \%, 3.5 \sim 7 \% \mathrm{Al}_{2} \mathrm{O}_{3}$ に対する 0.13 \% は著者らの得た $10 〜 17 \% \mathrm{SiO}_{2}$ に対する $0.15 \%, 1.3$ 〜 $5.2 \% \mathrm{Al}_{2} \mathrm{O}_{3}$ に対する $0.16 \%$ とよい近似を示してい る.

$$
\text { 5. 結 言 }
$$

以上, $\mathrm{X}$ 線カントレコーダにより鉄鋼スラッグ, セメ ント中の $\mathrm{Fe}, \mathrm{MnO}, \mathrm{CaO}, \mathrm{P}_{2} \mathrm{O}_{5}, \mathrm{SiO}, \mathrm{Al}_{2} \mathrm{O}_{3}$ などにつ き分析を行ない，その精度について検討を行なつた。本 実験では試料数が限られ詳細な検討を行なえなかつた が，いずれも日常分析に充分使用できる好結果を得，本 X線カントレコーダによる同時分析法は日常の迅速分析
に対して有効な手段であり，鉄鋼セメント工業の工程管 理の一手段として充分使用できるものと結論される.

なお本実験で充分解析し得なかつた諸点, たとえば, スラッグ中のの $\mathrm{MnO}$ 測定の場合, No. 6, No. 7 が特 に低く測定されたこと， スラッグ A中の Fe について $\sigma_{\text {obs. }} \sigma_{\text {call. }}$. 值が近接しているにかかわらず $\delta_{1}, \delta_{2}$ の 值に大きな差が生じた点, その他軽元素分析におけるパ ルス波高分布曲線の追跡および重元素高次線による妨害 の定量的な検討, また装置自体のさらに詳細な定量的性 能などについても今後なお検討を進めたいと考えてい る.

また本報告では $\mathrm{MgO}$ など残余の成分については取り あげなかつたが，これらはさらに分析困難と思われるの で彎曲結晶による集中法を用い, 今後も検討を行なうつ もりである.

\section{分 光 研 究 第 10 巻 第 4 号 \\ 蒸 発法用装置 の試 作 ${ }^{*}$ \\ 中島篤之助** 河口広 司**.高島教一郎**}

（昭和 37 年 4 月 19 日受理）

\section{Equipment for the Evaporation Method}

\section{Tokunosuke NAKAJIMA, Hiroshi KAWAGUCHI and Kyoichiro TAKASHIMA}

(Japan Atomic Energy Research Institute, Ibaraki-ken)

An apparatus is devised for the evaporation method or preliminary fractional distillation method in spectrographic analysis. As in a similar equipment described by Pszoniski ${ }^{6)}$, electric resistance heating is used, and a graphite crucible containing the sample serves as the heating element. Temperature measurements are carried out with a specially designed radiation pyrometer using a photomultiplier tube 931A. Electric current is controlled with the aid of a motor-driven moving iron core reactor. Volatile impurities are evaporated and collected on the top of a graphite or copper rod which is then used as the sample electrode for spectrographic determination. Distillation is carried out in air.

\section{1. 緒言}

酸化ウラン，酸化トリウムなどの高沸点基体物質中の 微量不純物を定量分光分析するためには, Scribner1)ら

* 昭和 36 年 10 月 28 日, 日本分析化学会第 10 年会に て講演

** 日本原子力研究所, 荻城県那珂郡東海村

1) B.F. Scribner and H.R. Mullin: J. Res, N.B. S., 37, 379 (1946).
の提案した担体蒸溜法が広く利用されている。著者らは この方法について種々の検討を㧍こなつてきたが233)，不 純物の蒸発におよぼす担体の作用, マトリックスの性質 の差による不純物の蒸発率の变化など, いくつかの問題 点が見出された. Mandel'shtam ${ }^{4)}$ およ゙゙ Zaidel ${ }^{5)} ら$

2) 中島・高橋・河口：日本金属学会誌, 22, 508 (1958).

3) 中島・福島: 分析化学, 9, 830 (1960). 